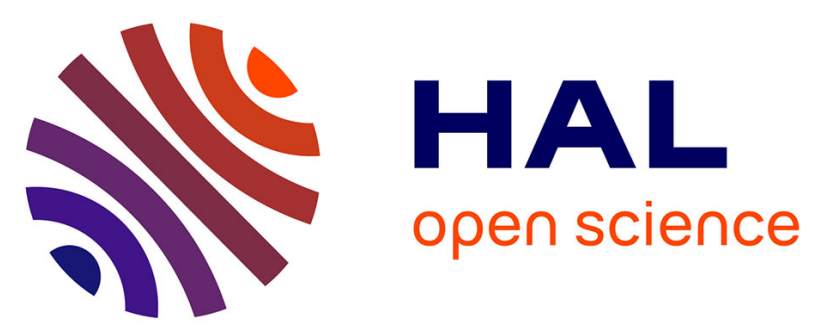

\title{
Men from Sub-Saharan Africa Living in Worker Hostels in France: A Hidden Population with Poor Access to HIV Testing
}

M. Guiguet, S. Dionou, J. Volant, M. C. Samba, N. Benammar, P. Chauvin, A. Simon

\section{To cite this version:}

M. Guiguet, S. Dionou, J. Volant, M. C. Samba, N. Benammar, et al.. Men from Sub-Saharan Africa Living in Worker Hostels in France: A Hidden Population with Poor Access to HIV Testing. Journal of Immigrant and Minority Health, 2016, pp.1-4. 10.1007/s10903-016-0385-3 . hal-01293028

\section{HAL Id: hal-01293028 https://hal.sorbonne-universite.fr/hal-01293028}

Submitted on 24 Mar 2016

HAL is a multi-disciplinary open access archive for the deposit and dissemination of scientific research documents, whether they are published or not. The documents may come from teaching and research institutions in France or abroad, or from public or private research centers.
L'archive ouverte pluridisciplinaire HAL, est destinée au dépôt et à la diffusion de documents scientifiques de niveau recherche, publiés ou non, émanant des établissements d'enseignement et de recherche français ou étrangers, des laboratoires publics ou privés. 
Men from sub-Saharan Africa living in worker hostels in France: a hidden population with poor access to HIV testing

M. Guiguet ${ }^{1}$, S. Dionou ${ }^{2,3}$, J. Volant ${ }^{4}$, M.C. Samba ${ }^{2}$, N. Benammar ${ }^{2}$, P. Chauvin ${ }^{1}$, A. Simon ${ }^{2}$

1. Sorbonne Universités, UPMC Univ Paris 06, INSERM, Pierre Louis Institute of Epidemiology and Public Health, (IPLES UMR_S 1136),F-75013, Paris, France

2. AP-HP, Hôpital Pitié Salpêtrière, CDAG-Department of Internal Medicine and Clinical Immunology, F-75013, Paris, France

3. COREVIH Ile-de-France Centre, F-75013, Paris, France

4. Fédération SOS Hépatite, F-75020, Paris, France

Corresponding author: Marguerite Guiguet, INSERM U1136, 56 bd Vincent Auriol, CS81393, 75646 Paris Cedex 13, France. Tel.: +33 1421642 77; Fax: +33 1421642 67; e-mail: marguerite.guiguet@inserm.fr

Running head: Poor access to HIV testing among migrants living in worker hostels in France

\section{Disclosure of potential conflicts of interest.}

Author MG declares that she has no conflict of interest. Author SD declares that he has no conflict of interest. Author JV declares that he has no conflict of interest. Author MCS declares that she has no conflict of interest. Author NB declares that she has no conflict of interest. Author PC declares that he has no conflict of interest. Author AS declares that she has no conflict of interest. 


\section{Abstract}

Background. Delayed presentation to care among HIV-infected individuals continued to be frequent in France. Migrants are at high risk for late presentation. This cross-sectional study investigated barriers to HIV testing in the specific population of men from sub-Saharan Africa living in four migrant worker hostels in Paris, France.

Methods. Factors associated with never having been tested for HIV were examined using logistic regression.

Results. In all, 550 men participated, coming mainly from Mali and Senegal, with $31 \%$ having lived in France for less than 5 years, and 25\% without any health insurance. Only $37 \%$ have ever been tested for HIV. Not having health insurance was the main risk factor for nevertesting (adjusted odds ratio (aOR), 2.4; 95\% confidence interval ( $\mathrm{Cl}$ ), 1.4 to 4.0 ).

Conclusion. Despite free and anonymous HIV testing available at dedicated public screening centers, $63 \%$ of men living in migrant worker hostels had never been tested for HIV.

Keywords: HIV; Never testing; African migrant; Men; France 


\section{INTRODUCTION}

Recently, the START study confirmed the benefit of early initiation of antiretroviral therapy for HIV-infected individuals (1), but delayed presentation to care among HIV-infected individuals is still frequent (2). In the Paris region, there are an estimated 13,000 HIVinfected people who are unaware of their HIV status (out of a population of 11.9 million). Modeling of France's so-called "hidden HIV epidemic" has suggested that a large proportion of these undiagnosed HIV-infected individuals are non-French heterosexual men (3). Migrants have been identified as being at risk for late presentation with awareness being raised of barriers to earlier testing, and specific HIV testing recommendations have been made to address this population in most European countries (4). In Paris, people living in migrant worker hostels constitute a hard-to-reach, predominantly male (94\%) population for which there are few public health statistics, population health surveys or, until now, targeted health-related interventions. Built mainly from the 1950 s to the 1970 s, the 49 hostels in Paris still house 12,700 people, with 8,600 beds available (5). Most (63\%) of the residents are from sub-Saharan Africa. In order to design optimal interventions relevant to this key population, a pilot study was conducted in a few hostels. We did not know how asking about health outside medical context would be received and the main issue was to validate the feasibility of health information sessions organized in living settings. We assessed HIV testing rate among the specific population of men living in migrant worker hostels and investigated factors associated with no lifetime HIV testing.

\section{METHODS}

\section{Settings}

Health education and prevention sessions with emphasis on testing and treatment for HIV, the hepatitis B virus (HBV), and hepatitis C virus (HCV) were organized in four migrant 
worker hostels located in the neighborhood with Paris's largest public hospital. A health navigator (S.D.) at this hospital has worked for many years with patients from sub-Saharan Africa. Between June 2012 and September 2014, seven sessions took place in the hostels' meeting rooms on a Friday evening (three evenings at one hostel, two evenings at another hostel, and one evening at each of the other two hostels). During these events, the residents were encouraged to have a confidential, face-to-face consultation with a healthcare worker for a rapid health check-up. The consultation was organized in a private room, with translation help from the health navigator, if necessary. Chronic pathologies, vaccinations, and recourse to HIV testing were reviewed with advices. In addition to age, three demographic variables in relationship with migration history were recorded: country of origin, year of immigration, and health insurance coverage. Health insurance coverage could be used as a proxy for administrative status. Both basic health insurance and the French universal health coverage are inaccessible to illegal immigrants. The state medical aid is dedicated to illegal immigrants after 3 months of residence in France but requires long and somewhat complex administrative procedures.

\section{Ethics statement}

The study had been reviewed by the Comité de Protection des Personnes Ile-de-France VI. All the participants were informed of the study and gave their consent.

\section{Statistical methods}

Descriptive statistics are shown as medians and interquartile ranges, or n's and percentages, with the comparisons based on the Kruskal-Wallis test for continuous variables or $\chi^{2}$ tests (or the Fisher exact test when the numbers were small) for categorical variables. Factors associated with never testing for HIV were studied using logistic regression. Statistical analyses were performed with SAS v9.3 software (SAS Institute Inc.). 


\section{RESULTS}

A total of 550 men had a consultation. Nearly all were from Sub-Saharan Africa (96\%), mainly Mali (74\%) and Senegal (14\%). The median age was 40 years (IQR, 33-51), with no difference between the hostels (Table 1). The median length of residence in France was 12 years (IQR, 3-23), with 29\%, 12\% and 59\% having lived in France for less than 5 years, 5 to 9 years, and 10 years or more, respectively. Nearly half of the participants reported having at least basic health insurance or the French universal health coverage, $22 \%$ were covered by the state medical aid, and $25 \%$ had no health insurance at all.

In all, $63 \%$ had never been tested for HIV. This proportion was similar in all but one of the hostels. As shown in Table 1, having no health insurance was the main risk factor for no previous HIV testing (adjusted odds ratio (aOR), 2.4; 95\% confidence interval (Cl), 1.4 to 4.0). The men who have lived in France for less than 5 years were twice as likely to report no previous testing than those with at least 10 years of residence $(\mathrm{aOR}, 1.9 ; 95 \% \mathrm{Cl}, 1.1$ to 3.5$)$. After adjustment, younger age was no longer associated with previous HIV testing, but the men over 50 years were more likely to have never been tested than those aged 30 to 39 years (aOR, 1.9; 95\% $\mathrm{Cl}, 1.1$ to 3.2 ).

\section{DISCUSSION}

French national policy makes migrants a priority for HIV screening, but our results strengthened our hypothesis of a gap in achieving universal voluntary HIV testing. Only $37 \%$ of the migrant men living in worker hostels who participated in health educational sessions in their living settings had been tested for HIV at least once in their lifetime, compared to a proportion of 57\% among a representative sample of men living in the Paris area in 2010 (6). 
Fear of stigma and lack of confidentiality have been reported as preventing HIV testing in migrants (4). With nearly half of participant likely illegal immigrants as indicated by their lack of common health insurance coverage, this pilot study evidenced a large feasibility of health information sessions and personal health review organized in living settings.

The four hostels were a convenient sample for the pilot study and were all located in close proximity to the hospital that organized health educational sessions. Based on an inventory of the 49 migrant worker hostels in Paris published in 2011 (5), we observed an higher percentage of people from Sub-Saharan Africa in our respondents than reported $(96 \%$ vs $63 \%)$. Unfortunately, due to a large overpopulation in migrant hostels, with 1.6 resident per official resident, no other demographic characteristics could be compared as only official residents were described in the report.

The main limitation of this study was the paucity of sociodemographic data. The men's residency status, from a legal standpoint, was unknown to us, but their length of residence in France may approximate it, since illegal immigrants can expect to become legal after a few years of residence. No data on education level, employment status or socio-occupational categories were collected either. However, living in collective dwellings, such as hostels for immigrants, instead of ordinary households many years after immigrating most likely reflects a less favorable financial situation (as well as the absence of a long-term partnership). The only other information we had was their health insurance status, which correlated, at least partially, with their employment and administrative statuses. Lastly, we did not have any data on their health care utilization. The circumstances surrounding previous HIV testing (e.g., voluntary or during a routine examination) were not known. 
The difference in HIV testing according to migration origin is controversial. An increased risk of delayed diagnosis has been observed among migrants (2), and there is an effort to close this gap. In surveys in the general population living in the Paris metropolitan area, $60 \%$ of men of sub-Saharan nationality reported having been tested for HIV during their lifetime (7, 8). However, these surveys did not include residents of worker hostels or non-Frenchspeaking people. Our results are the first ones in France that show how low the HIV screening rate can be in specific groups of foreigners, with only $37 \%$ of migrants living in worker hostels having been tested in their lifetime. This screening rate is of the same magnitude as that (around 30\%) reported annually by one of the largest medical nongovernmental organizations in France that serves migrant patients, who visit its network of free clinics. However, this population is much poorer and more excluded than that in our study, with half being undocumented and almost all living in poverty, including a fourth who have no source of income. We could not rule out the possibility that recall bias resulted in an underestimate of the proportion of men in our study who had previously been tested. However, the participants in all the studies were asked to recall their HIV testing history, so it is unlikely that the large differences in the proportions of first-time testers is due to this potential bias.

Many opportunities for HIV testing exist in France, with a total of 5.2 million HIV tests having been performed in 2013 (9). While there is systematic prenatal HIV testing for women, such testing is proposed less systematically to men during routine medical examinations. A study of newly HIV-diagnosed patients reported that $45 \%$ of sub-Saharan migrants who discovered their infection had never been tested, even though nearly all had had medical encounters 
during the three years preceding the diagnosis (10). Demographic, migratory and behavioral factors have been associated with HIV testing in migrants (4). Intrinsic cultural factors have been advanced for delayed diagnosis while barriers in accessing the health system are more likely at the root of missed opportunities (11). Assimilation status linked to duration of immigration and fluency to communicate in the host country language, as well as access to healthcare has been shown to predict access to HIV prevention (12). In our study, the main risk factor for never having been tested was having no health insurance which could reflect a more general distance to public services. To increase HIV testing opportunities, free and anonymous HIV testing is available at the 13 dedicated public screening centers across Paris. However, among migrants living in the Paris metropolitan area, the level of knowledge of these dedicated consultations was lower among those without health insurance (8). Even if no insurance is needed to avail oneself of these centers, the fear of being noticed can prevent migrants with illegal residence status from seeking out preventive healthcare in this city.

In conclusion, despite a broad offer of free HIV testing and regular campaigns promoting such screening, a large proportion of migrant men living in worker hostels still report never having been tested for HIV. To overcome barriers to HIV testing, a recent meta-analysis concluded that alternative approaches such as community-based HIV testing should be offered in addition to standard voluntary testing in healthcare facilities and providerinitiated HIV testing (13). Our results highlight the need to develop such new strategies adapted to specific populations. 


\section{ACKNOWLEDGEMENTS.}

We gratefully thank all the hostel residents and healthcare staff who participated in this study. Lastly we thank Mark Wikens for his valuable help in revising this article.

\section{COMPLIANCE WITH ETHICAL STANDARDS}

\section{Ethical approval}

All procedures performed were in accordance with the ethical standards of the institutional and/or national research committee and with the 1964 Helsinki declaration and its later amendments or comparable ethical standards. The study had been reviewed by the Comité de Protection des Personnes Ile-de-France VI.

Informed consent

Informed consent was obtained from all individual participants included in the study. 


\section{REFERENCES}

1. Lundgren JD, Babiker AG, Gordin F, Emery S, Grund B, Sharma S, et al. Initiation of antiretroviral therapy in early asymptomatic HIV infection. N Engl J Med. 2015;373(9):795807.

2. Mocroft A, Lundgren JD, Sabin ML, Monforte A, Brockmeyer N, Casabona J, et al. Risk factors and outcomes for late presentation for HIV-positive persons in Europe: results from the Collaboration of Observational HIV Epidemiological Research Europe Study (COHERE). PLOS Med. 2013;10(9):e1001510.

3. Supervie V, Ndawinz J, Lodi S, Costagliola D. The undiagnosed HIV epidemic in France and its implications for HIV screening strategies. AIDS. 2014;28:1797-804.

4. Blondell SJ, Kitter B, Griffin MP, Durham J. Barriers and facilitators to HIV testing in migrants in high-income countries: a systematic review. AIDS Behav. 2015;19(11):2012-24

5. APUR (2011). Les foyers de travailleurs migrants à Paris : État des lieux en 2010 et inventaires des interventions sociales, sanitaires et culturelles. Agence parisienne d'urbanisme. Paris. Retrieved 2016-02-07 from http://www.apur.org/sites/default/files/ documents/foyers-travailleurs-migrants-paris.pdf

6. Massari V, Lapostolle A, Grupposo MC, Dray-Spira R, Costagliola D, Chauvin P. Which adults in the Paris metropolitan area have never been tested for HIV? A 2010 multilevel, cross-sectional, population-based study. BMC Infect Dis. 2015;15:278.

7. Lapostolle A, Massari V, Beltzer N, Halfen S, Chauvin P. Differences in recourse to HIV testing according to migration origin in the Paris metropolitan area in 2010. J Immigrant Minority Health. 2013;15:842-5. 
8. Le Vu S. Connaissances et pratiques liées au dépistage du VIH. In: Lydié N, ed. Les populations africaines d'lle-de-France face au VIH/SIDA : connaissances, attitudes, croyances et comportements. Paris: Editions INPES; 2007: 129-43.

9. Cazein F, Le Strat Y, Sarr A, Ramus C, Bouche N, Le Vu S, et al. Dépistage de l'infection par le VIH en France, 2003-2013. Bull Epidémiol Hebd. 2013;(33-34):534-40.

10. Champenois K, Cousien A, Cuzin L, Le Vu S, Deuffic-Burban S, Lanoy E, et al. Missed opportunities for HIV testing in newly-HIV-diagnosed patients, a cross sectional study. BMC Infect Dis. 2013;13:200.

11. Adedimeji AA, Absibon A, O'Connor G, Carson R, Cowan E, McKinley P, et al. Increasing HIV testing among African Immigrants in Ireland: Challenges and opportunities. J Immigrant Minority Health 2015; 17:89-95

12. Glasman LR, Weinhardt LS, Hackl KL. Disparities in access to HIV prevention among men of mexican descent living in the midwestern United States. J Immigrant Minority Health 20122; 13:1125-1133

13. Suthar A, Ford N, Bachanas P, Wong V, Rajan J, Saltzman A, et al. Towards universal voluntary HIV testing and counselling : A systematic review and meta-analysis of communitybased approaches. PLOS Med. 2013;10(8):e1001496. 
Table 1: Characteristics of 550 men living in four migrant worker hostels in Paris, France, and factors associated with no lifetime HIV testing

\begin{tabular}{|c|c|c|c|c|c|c|}
\hline & $\mathrm{N}$ & $\%$ never tested & Crude $\mathrm{OR}^{\circ}(95 \% \mathrm{Cl})$ & $p$ & Adjusted OR (95\% Cl) & $p$ \\
\hline Age & & & & 0.09 & & 0.15 \\
\hline $16-29$ years & 91 & 72.5 & $1.88(1.06-3.33)$ & & $1.09(0.55-2.13)$ & \\
\hline $30-39$ years & 163 & 59.5 & Ref. & & Ref. & \\
\hline $40-49$ years & 138 & 56.5 & $0.92(0.58-1.47)$ & & $1.20(0.72-2.01)$ & \\
\hline 50 years and over & 151 & 64.9 & $1.18(0.74-1.88)$ & & $1.89(1.11-3.23)$ & \\
\hline Length of residence in France & & & & 0.003 & & 0.08 \\
\hline $0-4$ years & 158 & 74.1 & $2.10(1.38-3.10)$ & & $1.92(1.06-3.50)$ & \\
\hline $5-9$ years & 62 & 62.9 & $1.35(0.76-2.41)$ & & $1.56(0.83-2.93)$ & \\
\hline 10 or more years & 317 & 56.8 & Ref. & & Ref. & \\
\hline Health insurance $(\mathrm{HI})^{*}$ & & & & $<0.0001$ & & 0.001 \\
\hline Yes & 407 & 57.7 & Ref. & & Ref. & \\
\hline No & 134 & 77.6 & $2.66(1.67-4.22)$ & & $2.37(1.41-3.97)$ & \\
\hline Hostels & & & & 0.07 & & 0.12 \\
\hline $\mathrm{A}$ & 214 & 59.4 & Ref. & & Ref. & \\
\hline B & 201 & 70.7 & $1.51(0.99-2.29)$ & & $1.37(0.89-2.11)$ & \\
\hline C & 57 & 54.4 & $0.80(0.44-1.46)$ & & $0.79(0.43-1.45)$ & \\
\hline D & 78 & 56.4 & $0.84(0.49-1.44)$ & & $0.79(0.45-1.37)$ & \\
\hline
\end{tabular}

* Basic HI with or without supplementary $\mathrm{HI}(\mathrm{n}=214,39.6 \%)$, French universal health coverage $(\mathrm{n}=33,6.1 \%)$, state medical aid $(\mathrm{n}=120,22.2 \%)$, or private $\mathrm{HI}(\mathrm{n}=40,7.4 \%)$. 